\title{
Successful Establishment of In Vitro Cultures of Prunus cerasifera Hybrids by Embryo Culture of Immature Fruits
}

\author{
A. Arbeloa, M.E. Daorden, E. García and J.A. Marín. \\ Estación Experimental Aula Dei (CSIC) \\ Apartado 202, 50080 Zaragoza. Spain. \\ arbeloa@eead.csic.es
}

Keywords: Rootstock breeding, embryo rescue, micropropagation, myrobalan, apricot

\begin{abstract}
Rapid obtaining of clonal plants is desirable to shorten crossing programs in fruit tree breeding. In this work, seedling germination and multiplication in vitro allowed us to establish successful in vitro cultures of hybrid seedlings. As a part of a breeding program in apricot rootstocks, we have obtained interespecific hybrid seeds after cross-pollination: myrobalan $\mathrm{x}$ apricot (Prunus cerasifera $\times$ armeniaca). Immature fruits were harvested and embryos, isolated in aseptic conditions, were grown in culture medium. From a total of 419 seeds, we obtained a germination rate of $81.4 \%$, succeeding in the rescue of $73 \%$ of aborting seeds. The successful micropropagation and acclimatization methods applied, yielded a high number of cloned plants from every cultured embryo, allowing us to obtain soil-established plants in a very short time. Advantages of in vitro germination and micropropagation versus conventional methods have been assessed from the point of view of the length of the process and the number of clonal plants obtained.
\end{abstract}

\section{INTRODUCTION}

Rootstock breeding program based on interspecific crosses and conventional propagation and selection methods are a very slow process. In vitro germination of embryos and micropropagation can be a very useful tool in multiplying and obtaining larger number of hybrids in a shorter time.

Embryo culture has been successfully used in fruit tree breeding programs. Blake (1939) established for the first time embryo culture for peach breeding and later it has been mainly used in early maturing-peach (Ramming, 1985) and seedless Vitis breeding (Emershad, Ramming, 1982)

Embryo rescue has also been successfully used to overcome the lack of viability in interspecific hybrids. It is useful when there is poor embryo development or abortion. Post-zygotic barriers in interspecific hybrids are a common occurrence but they can be overcome through the use of embryo rescue (Ramming, 1990).

As a part of a breeding program in apricot rootstocks, we have obtained interspecific hybrid seeds after cross-pollination: myrobalan x apricot (Prunus cerasifera $\times$ armeniaca). Embryo rescue together with plant micropropagation has been applied allowing the successful establishment of in vitro culture of hybrid seedlings.

\section{MATERIALS AND METHODS}

\section{Embryo culture}

Seeds were obtained by hand cross-pollinating three clones of myrobalan flowers with apricot pollen, cv. Moniquí. Flowering took place on February and 9 weeks later 
immature fruits were harvested. Seeds were extracted from fruits in aseptic conditions and embryos were dissected and measured. Cheé and Pool (1987) medium with thiamine $(1.19 \mu \mathrm{M})$ and sucrose $(87.6 \mu \mathrm{M})$ but without growth regulators were used as germination medium.

After a period of stratification at $4^{\circ} \mathrm{C}$ in the dark, seeds were placed in a cultivation chamber at $24^{\circ} \mathrm{C}$ with a photoperiod of 16 hours and $35 \mu \mathrm{mol} \cdot \mathrm{m}^{-2} \cdot \mathrm{s}^{-1}$ of light intensity. Embryos were considered germinated when they had developed a shoot of $5 \mathrm{~mm}$.

\section{Plant propagation and establishment}

After germination, shoots were separated from root and cotyledons, multiplied in a modified Murashige and Skoog (1962) medium with IBA $(0.5 \mu \mathrm{M})$ and BAP $(5 \mu \mathrm{M})$, and subcultivated every month evaluating their multiplication rate.

Once a sufficient number of shoots were obtained, plants were rooted in a similar medium with IBA $(5 \mu \mathrm{M})$ and without BAP. Rooting rate was evaluated after one month and rooted plants were transplanted to soil in the greenhouse at that time. Plant acclimatization was performed by increasing exposures to low relative humidity in a plastic tent (Marín, this volume).

\section{RESULTS AND DISCUSSION \\ Embryo germination in vitro}

In vitro embryo germination leads to successful germination rates (Table 1) and to the rescue of most of the abortive embryos. During stratification, germination occurs in a non-simultaneous way showing different degrees of development in the seeds. The mean germination rate obtained was $81.4 \%$ and no contamination was observed during the process. These results indicate that this protocol is adequate for hybrid seed germination.

Length of the embryos at sowing date ranged between 0.5 and $10 \mathrm{~mm}$. We considered abortive seeds those with less than 8-mm in length. From 419 seeds, 42.5\% were smaller than 8 -mm and $57.5 \%$ were $8-10 \mathrm{~mm}$ in length. Among abortive seeds $(<8$ $\mathrm{mm}$ ), $73 \%$ germinated and developed into plantlets (Table 1 ).

Success in embryo culture is related to maturation stage of the embryo, which is directly related with size (Burgos and Ledbetter, 1993). Very small embryos do not develop in vitro (Pierick, 1990). In this work, we have compared germination rates of different embryo sizes and also observed that germination rate strongly decreases with size. Only a $27 \%$ of embryos, ranged $0,5-4 \mathrm{~mm}$ in length, germinated. However, $85,1 \%$ germination ocurred when embryo size ranged $4-7,5 \mathrm{~mm}$ in length and it rose to $87 \%$ when embryo size ranged 8-10 mm in length (Table 1).

\section{Plant micropropagation and establishment}

The multiplication rate of the different clones in modified MS medium was 4 shoots per shoot, showing no significant differences among the evaluated clones (157). When an appropriate number of shoots per clone was obtained (> 30 shoots/clone), shoots were placed in rooting medium. One month later 95\% rooting was achieved, then plant acclimatization was undertaken. Plants were transplanted into jiffy-pots with a peatvermiculite (1:1) substrate, and then placed in a humid plastic tent, where increasing exposures to low relative humidity were supplied during 50 days (Marín, this volume), and survival rate was $90 \%$. Acclimatized plants were transplanted to pots and later to a frame outdoors. 


\section{Conventional versus in vitro methods}

Advantages of in vitro germination and micropropagation versus conventional methods have been assessed from the point of view of the timing of the process and the number of clonal plants obtained (Table 2).

By conventional methods we can obtain in 20 months a unique plant per clone that must be multiplied before evaluation (Herrero, 1978). By in vitro methods we have obtained in 14 months so much plants per clone as we need to evaluate. The successful micropropagation and acclimatization methods applied in this work leaded into a higher number of cloned plants per genotype in a shorter time. Besides, the establishment of in vitro culture of hybrid seedlings allows the possibility of applying early selection methods as callus incompatibility evaluation (Errea et al 2001).

Advantages of in vitro technique are also related to the number of different genotypes obtained by abortive embryo rescue. Interspecific hybrids in Prunus show diverse incompatibility barriers (Layne and Sherman, 1986). A 73\% of abortive hybrid seeds $(<8 \mathrm{~mm})$ have been able to germinate and develop into plantlets. Thus, we have obtained, by embryo rescue, a higher number of clones to evaluate. Otherwise, these seeds would never be able to germinate by conventional methods.

\section{CONCLUSSIONS}

In vitro methods lead to obtain a higher number of genotypes by embryo rescue and a higher number of plants per genotype in a shorter time. The establishment of in vitro cultures of hybrid seedlings allows the possibility of starting the evaluation by six months after germination, and the plants obtained are prepared for early selection methods.

\section{ACKNOWLEDGMENTS}

This work was supported by projects CONSI+D-DGA P54/98 and CICYT AGF98-0277-C4-01

\section{Literature cited}

Blake, M.A. 1930. Some results of crosses of early ripening varieties of peach. Proc. Amer. Soc. Hort. Sci. 37: 232-241

Burgos, L. and Ledbetter, C.A. 1993. Improved efficiency in apricot breeding. Effects of embryo development and nutrient media on in vitro germination and seedling establishment. Plant Cell Tissue Organ Cult. 35: 217-222

Cheé, R. and Pool R.M. 1987. Improved inorganic media constituents for in vitro shoot multiplication of Vitis. Sci. Hortic. 32: 85-95

Emershad, R.L. and Ramming D.W. 1982. In ovulo embryo culture of Vitis vinifera L. cv. 'Thompson Seedless'. HortSciene 17: 576

Errea, P., Garay, L. and Marín J.A. 2001. Early detection of graft incompatibility in apricot (Prunus armeniaca) using in vitro techniques. Physiol. Plant. 112: 135-141

Herrero, J. 1978. Estratificado de huesos de ciruelo Mirobolán (Prunus cerasifera Ehrh.) An. Est. Exp. Aula Dei 14: 173-180

Layne, R.E.C. and Sherman, W.B. 1986. Interspecific hybridization of Prunus. HortScience 21: 48-51

Marín, J.A. 2001 High survival rates during acclimatization of micropropagated fruit tree rootstocks by increasing exposures to low relative humidity. Acta Hort. (this volume) 
Murashige, T. and Skoog, F. 1962. A revised medium for rapid growth and bioassays with tobacco tissue cultures. Physiol. Plant. 15: 473-479

Pierik, R.L.M. 1990. Cultivo de embriones. In: Cultivo in vitro de las plantas superiores. Ediciones Mundi-Prensa, Madrid. pp: 139-147

Ramming, D.W. 1985. In ovulo embryo culture of early-maturing Prunus. HortSience 20: 419-420

Ramming, D.W. 1990. The use of embryo culture in fruit breeding. HortScience 25: 393398

\section{$\underline{\text { Tables }}$}

Table 1. Number of embryos at sowing date and their germination rates

\begin{tabular}{|c|c|c|c|c|}
\cline { 2 - 5 } \multicolumn{1}{c|}{} & $\mathbf{0 . 5}-\mathbf{3 . 5} \mathbf{~ m m}$ & $\mathbf{4 - 7 . 5 ~} \mathbf{~ m m}$ & $\mathbf{8 - 1 0} \mathbf{~ m m}$ & Total \\
\hline No. Embryos & 37 & 141 & 241 & 419 \\
\hline$\%$ & 8.80 & 33.60 & 57.50 & 100 \\
\hline No. germinated embryos & 10 & 120 & 211 & 341 \\
\hline$\%$ & 27.00 & 85.10 & 87.50 & 81.40 \\
\hline
\end{tabular}

Table 2. Conventional versus in vitro method to obtain hybrid myrobalan x apricot plants

\begin{tabular}{|c|c|c|}
\hline Conventional method & Month & In vitro culture method \\
\hline \multirow[t]{2}{*}{ Crossing pollination } & March & Crossing pollination \\
\hline & May & $\begin{array}{c}\text { Embryo rescue } \\
\text { Beginning of stratification }\end{array}$ \\
\hline Fruit maturation & July & \\
\hline \multirow{3}{*}{ Beginning of stratification } & September & \\
\hline & October & $\begin{array}{l}\text { End of stratification } \\
\text { Germination }\end{array}$ \\
\hline & November & Micropropagation \\
\hline End of stratification & December & \\
\hline \multirow[t]{2}{*}{ Germination } & January & \\
\hline & February & Rooting \\
\hline \multirow[t]{2}{*}{ Sowing } & March & Acclimatization \\
\hline & April & Orchard cultivation \\
\hline Nursery transplanting & January & \\
\hline $\begin{array}{ll} & \text { PLANT TO MULTIPLY } \\
- & \text { Only viable seeds. } \\
- & \text { A unique plant per genotype. }\end{array}$ & & $\begin{array}{ll} & \text { PLANT TO EVALUATE } \\
- & \text { Abortive embryo rescue } \\
- & \text { Numerous plants per genotype } \\
- & \text { Early selection availability }\end{array}$ \\
\hline
\end{tabular}

